\title{
ТРУДОВЕ ПРАВО
}

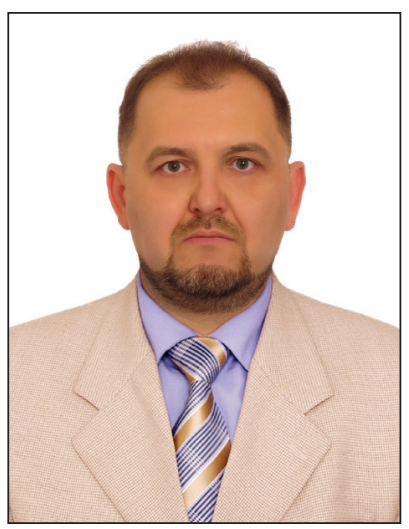

Ярошенко Олег Миколайович,

доктор юридичних наук, професор,

член-кореспондент Начіональної академії

правових наук України,

завідувач кафедри трудового права,

Начіональний юридичний університет

імені Ярослава Мудрого, Україна, м. Харків

e-mail:yaroshenkolex@ukr.net

ORCID 0000-0001-9022-4726

doi: 10.21564/2414-990x.145.159672

YAK 349.22

\section{ПРОБАЕМИ ЗАБЕЗПЕЧЕННЯ КОНСТИТУЦІЙНОГО ПРАВА ГРОМААЯН НА АОСТАТНІЙ ЖИТТЄВИЙ РІВЕНЬ}

Згідно з Конституцією Украӥни 1996 р. держава забезпечує сощіальну спрямованість економіки (ч. 4 ст. 13). Це у свою чергу є основою для реалізаціі численних соціальних прав громадян, зокрема на заробітну плату, не нижч від визначеної законом (cm. 43), соціальний захист (ст. 46), а також достатній життєвий рівень для себе і своєї сім'і (ст. 48). Зазначені норми Основного Закону реалізуються передбаченими чинним законодавством державними соціальними стандартами і державними сочіальними гарантіями. У статті доведено, що чинні начіональні законодавчі акти, що визначають правові засади формування $і$ застосування державних сочіальних стандартів і нормативів, спрямованих на реалізацію закріплених Конституцією та законами Украйни основних соціальних гарантій, чіткої та однозначної відповіді на питання, що є достатній життєвий рівень, який зміст відповідного права та як воно забезпечується, не містять.

Аналіз міжнародних документів показав, що для позначення фактично одного і того ж явища використовуються різні терміни: «достатній життєвий рівень»; «гідний життєвий рівень»; «життєвий рівень, який є необхідним для підтримання здоров'я $і$ добробуту»; «адекватний сочіальний захист».

Зрозуміло, що достатній життєвий рівень не є усталеною величиною, позаяк він змінюється залежно від сочіально-економічних та інших чинників. Завдання держави полягає у створенні належних умов для людини, щоб вона могла своєю пращею забезпечити гідну матеріальну базу як для себе, так і своєї сім'ї. Обстоюється позиція, що правильніше говорити не про достатній, а про гідний життєвий рівень, адже у першому випадку йдеться про рівень, який фактично відповідає мінімальним потребам людини (тобто той, що дорівнюе або є вищим межі бідності людини), значення ж другого полягає у тому, що це рівень, який виходить із того, що для людини є найвищою соціальною щінністю. Саме гідність дає змогу людині відчувати самоповагу й усвідомлювати власну суспільну цінність. Ця позиція має бути зафіксована і у ст. 48 Конституцї̈ України.

Ключові слова: соціальні права; соціальний захист; право на достатній життєвий рівень; державні соціальні стандарти; державні соціальні гарантії; прожитковий мінімум; бідність. 
Ярошенко О. Н., доктор юридических наук, профессор, член-корреспондент Национальной академии правовых наук Украины, заведующий кафедрой трудового права, Национальный юридический университет имени Ярослава Мудрого, Украина, г. Харьков.

e-mail : yaroshenkolex@ukr.net ; ORCID 0000-0001-9022-4726

\section{Проблемы обеспечения конституционного права граждан на достаточный жизненный уровень}

Согласно Конститущии Украины 1996 г. государство обеспечивает социальную направленность экономики (ч. $4 \mathrm{~cm} .13)$. Это в свою очередь является основой для реализации многочисленных социальных прав граждан, в частности на заработную плату, не ниже той, что определена законом (ст. 43), социальную защиту (cm. 46), а также достаточный жизненный уровень для себя и своей семьи (ст. 48). Указаннье нормы Основного Закона реализуются предусмотренными действующим законодательством государственными социальными стандартами и государственными социальными гарантиями. Однако действующие национальные законодательные акты, определяющие правовые принципь формирования и применения государственных социальных стандартов и нормативов, направленных на реализащию закрепленных Конститущией и законами Украины основных социальных гарантий, четкого и однозначного ответа на вопрос, чем является достаточный жизненный уровень, какое содержание соответствующего права, и как оно обеспечивается, не содержат.

Анализ международных документов показал, что для обозначения фактически одного и того же явления употребляются разные термины: «достаточный жизненный уровень»; «достойный жизненный уровень»; «жизненный уровень, являющийся необходимым для поддержания здоровья и благосостояния»; «адекватная сочиальная защита».

Понятно, что достаточный жизненный уровень не является устоявшейся величиной, поскольку он изменяется в зависимости от сочиально-экономических и других факторов. Задача государства заключается в создании надлежащих условий для человека, чтобы он мог своим трудом обеспечить достойную материальную базу как для себя, так и своей семьи. Отстаивается позищия, согласно которой правильнее говорить не о достаточном, а о достойном жизненном уровне, ведь в первом случае речь идет об уровне, фактически отвечающем минимальным потребностям человека (то есть о том, который равняется или является выше границы бедности человека), значение же второго заключается в том, что это уровень, исходящий из того, что человек является наивысшей социальной ценностью. Именно достоинство дает возможность человеку чувствовать самоуважение и осознавать собственную общественную ценность. Эта позиция должна быть зафиксирована и в ст. 48 Конституции Украины.

Ключевые слова: социальные права; социальная защита; право на достаточный жизненный уровень; государственные социальные стандарты; государственные социальные гарантии; прожиточный минимум; бедность.

Постановка проблеми. Згідно з Конституцією України держава забезпечує соціальну спрямованість економіки (ч. 4 ст. 13). Це у свою чергу є основою для реалізації численних соціальних прав громадян, зокрема на заробітну плату, не нижчу від встановленої законом (ст. 43), соціальний захист (ст. 46), а також достатній життєвий рівень для себе і своєї сім'ї (ст. 48). Зазначені норми Основного Закону реалізуються шляхом передбачених чинним законодавством державних соціальних стандартів і державних соціальних гарантій, визначених Законом України «Про державні соціальні стандарти та державні соціальні гарантіі» від 5 жовтня 2000 р. [2]. Поряд із законодавчим встановленням найбільш важливих соціальних стандартів і нормативів, диференційованим за соціально-демографічними ознаками підходом до визначення цим нормативів, 
гласністю і громадським контролем при їх визначенні та застосуванні, науковою обгрунтованістю норм споживання і забезпечення, соціальним партнерством, урахуванням вимог міжнародних стандартів у сфері соціального захисту і трудових відносин, формування стандартів і нормативів здійснюється за принципом забезпечення конституційно визначених соціальних прав і державних соціальних гарантій достатнього життєвого рівня для кожного. Однак ні у названих, ні в інших чинних національних законодавчих актах, що визначають правові засади формування і застосування державних соціальних стандартів і нормативів, спрямованих на реалізацію закріплених Конституцією і законами України основних соціальних гарантій, чіткої й однозначної відповіді на питання, що є достатній життєвий рівень, який зміст відповідного права, та як воно забезпечується, отримати не можна. Створити надійний фундамент, який правозастосовувачам дозволить уникнути або подолати відповідні проблеми, а законодавців спонукатиме до активного нормотворення в означеній царині, і покликана юридична наука.

Аналіз останніх джерел $\boldsymbol{i}$ публікащій. Теоретико-прикладна проблема належної реалізації громадянином конституційного права на достатній життєвий рівень стала об'єктом наукового інтересу вітчизняних учених-правників вже після проголошення незалежності України. Протягом радянського періоду вона замовчувалася. Окремим i аспектам, більшою чи меншою мірою, присвячені наукові праці С. С. Алексєєва (S. S. Aleksieiev), О. С. Арсентьєвої (О. S. Arsentieva), Ю. Г. Барабаша (Yu. Н. Barabash), О. В. Бермічевої (O. V. Bermicheva), В. М. Вегери (V. M. Vehera), Ю. Ю. Івчук (Yu. Yu. Ivchuk), А. М. Колодія (А. M. Kolodii), В. В. Мацокіна (V. V. Matsokin), О. В. Москаленко (O. V. Moskalenko), С. М. Прилипка (S. M. Prylypko), П. М. Рабіновича (P. M. Rabinovych), Б. I. Сташківа (B. I. Stashkiv), Л. П. Шумної (L. P. Shumna), О. М. Ярошенка (О. М. Yaroshenko) та ін.

Mema cmammi - на підставі міжнародних і національних законодавчих актів у сфері праці та соціального забезпечення, практики їх застосування компетентними державними органами, висновків та ідей фахівців-юристів, з'ясувати сутність і правову природу права на достатній життєвий рівень, його місце в системі конституційних прав людини і громадянина, а також визначити проблеми забезпечення цього права і запропонувати шляхи їх вирішення.

Виклад основного матеріалу. Конституція України у ст. 48 проголошує: «Кожен має право на достатній життєвий рівень для себе і своєї сім’ї, що включає достатнє харчування, одяг, житло».

Це конституційне положення - яскравий приклад упровадження в національне українське право загальновизнаних міжнародних стандартів у царині прав людини. Адже за ст. 25 Загальної декларації прав людини 1948 р. [3] кожна людина має право на такий життєвий рівень, який є необхідним для підтримання здоров’я і добробуту i самої та ㄲi⿺ сім’i, i право на забезпечення в разі безробіття, хвороби, інвалідності, вдівства, старості чи іншого випадку втрати засобів до існування через незалежні від неї обставини. Перше із перера- 
хованих прав включає їжу, одяг, житло, медичний догляд і необхідне соціальне обслуговування. Наведений постулат розвинено у ст. 11 Міжнародного пакту про економічні, соціальні і культурні права 1966 р. [4], за якою держави, що беруть участь у ньому, визнають право кожного на достатній життєвий рівень для нього і його сім'ї, що передбачає достатнє харчування, одяг і житло, і на неухильне поліпшення умов життя. Держави вживуть належних заходів щодо забезпечення здійснення цього права, визнаючи важливе значення в цьому відношенні міжнародного співробітництва, заснованого на вільній згоді. Держави, визнаючи основне право кожної людини на свободу від голоду, повинні вживати необхідних заходів індивідуально і в порядку міжнародного співробітництва, які б включали проведення конкретних програм для того, щоб: а) поліпшити методи виробництва, зберігання і розподілу продуктів харчування шляхом широкого використання технічних і наукових знань, поширення знань про принципи харчування і вдосконалення або реформи аграрних систем так, щоб досягти найбільш ефективного освоєння і використання природних ресурсів; б) забезпечити справедливий розподіл світових запасів продовольства відповідно до потреб і з урахуванням проблем країн, що імпортують чи експортують продукти. За статею 28 «Достатній життєвий рівень та соціальний захист» Конвенції про права осіб з інвалідністю 2006 р. [5] держави визнають право осіб з інвалідністю на достатній життєвий рівень для них самих і їх сімей, що включає достатнє харчування, одяг та житло, і на безперервне поліпшення умов життя й вживають належних заходів для забезпечення і заохочення реалізації цього права без дискримінації за ознакою інвалідності. Розділ II Конвенції МОП № 117 «Про основні цілі та норми соціальної політики» 1962 p. [6] має назву «Підвищення рівня життя» і розглядає таке підвищення як основну мету при плануванні економічного розвитку. При плануванні останнього вживаються всі можливі заходи для узгодження такого розвитку зі здоровою еволюцією відповідних груп населення. Зокрема, докладаються зусилля 3 метою запобігання руйнуванню сімейного життя і традиційних соціальних одиниць, особливо шляхом: ретельного вивчення причин і наслідків міграції і вжиття в разі потреби відповідних заходів; сприяння міському та сільському плануванню в регіонах, де потреби економічного розвитку призводять до концентрації населення; запобігання й усунення перенаселеності в міських зонах; поліпшення умов життя в сільських місцевостях і створення відповідних галузей промисловості там, де є відповідна робоча сила. Вживаються заходи для забезпечення незалежним виробникам і найманим працівникам умов, які дадуть їм можливість підвищити свій рівень життя власними зусиллями й забезпечать підтримання прожиткового мінімуму, що встановлюється шляхом офіційних досліджень життєвих умов, які проводяться після консультацій 3 представниками організацій роботодавців і працівників. При встановленні прожиткового мінімуму беруться до уваги такі основні сімейні потреби працівників, як продукти харчування і їх калорійність, забезпечення житлом, одягом, медичне обслуговування та освіта. 
До питання забезпечення гідного людини рівня життя неодноразово зверталась і продовжує звертатись європейська наукова спільнота. Так, ч. XI «Норми, яким мають відповідати періодичні грошові виплати» Європейського кодексу соціального забезпечення 1964 р. [7] виходить із того, що розмір допомоги встановлюється відповідно до визначеної шкали чи шкали, запровадженої компетентним органом державної влади. Цей розмір може бути скорочено, тільки якщо інші засоби існування сім”ї бенефіціарія перевищують визначені основні суми чи основні суми, встановлені компетентним органом державної влади. При цьому загальний розмір допомоги та будь-яких інших засобів існування після вирахування зазначених вище сум має бути достатнім для утримання сім’ї у здоровому й гідному стані. Хартія Співтовариства про основні соціальні права працівників 1989 р. [8] у ст. 5 фіксує, що всі види зайнятості підлягають справедливій винагороді. 3 цією метою працівникам забезпечується справедлива заробітна плата, тобто заробітна плата, достатня для забезпечення їм гідного рівня життя. Стосовно соціального захисту ст. 10 розглядуваного акта закріплює, що кожний працівник Європейського Співтовариства має право на адекватний соціальний захист, і незалежно від статусу і розміру підприємства, на якому працює, користуватися адекватним рівнем допомоги з соціального забезпечення. Відповідно до Європейської соціальної хартії (переглянутої) 1996 р. [9] з метою забезпечення ефективного здійснення права на справедливу винагороду держави зобов'язуються визнати право працівників на таку винагороду, яка забезпечує їм і їх сім'ям достатній життєвий рівень (ст. 4). У свою чергу з метою забезпечення реалізації права на захист від бідності та соціального відчуження Сторони зобов'язуються: а) у рамках загального та узгодженого підходу вживати заходів для надання особам, що живуть або можуть опинитися в ситуації соціального відчуження або бідності, а також членам їх сімей, ефективного доступу, зокрема, до роботи, житла, професійної підготовки, освіти, культури і соціальної та медичної допомоги; б) переглядати ці заходи з метою їх коригування у разі необхідності (ст. 30).

Аналіз наведених та інших міжнародних документів показує, що для позначення фактично одного і того ж явища використовуються різні терміни: «достатній життєвий рівень»; «гідний життєвий рівень»; «життєвий рівень, який є необхідним для підтримання здоров'я і добробуту»; «адекватний соціальний захист».

На думку О. В. Бермічевої, сутність права людини на достатній життєвий рівень складають умови, що їх створює держава для його реалізації, зміст же утворюють заходи, що вживаються нею для забезпечення цього права, а формою виступає передбачення законодавчо встановлених мінімальних соціальних стандартів [10, с. 56-57].

В. В. Мацокін право людини на достатній життєвий рівень називає інтегруючим соціальним правом, що об'єднує собою не лише всі інші соціальні права в одну цілісну систему, але й зумовлює сутність і зміст правового регулювання більшості громадянських і політичних прав. Правознавцем доведено, що розгля- 
дуване право є одним з найбільш важливих і соціально значущих для кожної людини. Забезпечення ж цього права є метою діяльності кожної демократичної країни й одним з основоположних конституційних принципів будь-якої сучасної держави. Це право слід розглядати в двох взаємопов’язаних аспектах: з одного боку, держава створює умови, за яких кожна здорова, дієздатна людина має реальні можливості забезпечити такий рівень свого життя, який відповідає іiі уявленням; з другого - держава зобов'язана використовувати всі свої матеріальні, політичні, організаційні й інші ресурси задля забезпечення достатнього життєвого рівня соціально незахищених верств населення [11, с. 10-11].

Згідно зі ст. 25 Основ законодавства України про охорону здоров’я від 19 листопада 1992 р. [12] з метою досягнення належного життєвого рівня, враховуючи науково обгрунтовані медичні, фізіологічні і санітарно-гігієнічні вимоги, держава: а) встановлює єдині мінімальні норми заробітної плати, пенсій, стипендій, соціальної допомоги й інших доходів населення; б) організує натуральне забезпечення населення продуктами харчування, одягом, ліками та іншими предметами першої необхідності; в) здійснює комплекс заходів щодо задоволення життєвих потреб біженців, безпритульних та інших осіб, які не мають певного місця проживання; г) безплатно надає медичну допомогу й соціальне обслуговування особам, які перебувають у скрутному матеріальному становищі, загрозливому для їх життя і здоров’я.

Рівень життя - багатогранна і складна категорія. Вона характеризує сукупність реальних соціально-економічних умов життєдіяльності людей, а тому є найважливішою характеристикою соціального процесу. Передумови для підвищення рівня життя населення країни створюються відповідним економічним розвитком. Останній є ресурсоутворюючим фактором для реалізації соціальних програм. У цьому виявляється тісний взаємозв’язок між економічним зростанням і соціальним прогресом. Аналіз рівня життя населення передбачає вивчення процесів, явищ і факторів, що впливають на життєдіяльність людей, їх матеріальні умови, при цьому розглядаються ключові проблеми соціально-економічного розвитку, які підлягають першочергомому вирішенню. Добре налагоджена система показників рівня життя має велике значення для розробки ефективної соціальної політики; прийняття обгрунтованих рішень щодо надання допомоги малозабезпеченому населенню; оцінки соціально-економічних наслідків проведених у країні реформ; здійснення контролю за ходом реалізації найважливіших державних соціальних програм.

Статистичні характеристики рівня життя грунтуються на широкій системі взаємозалежних показників, що забезпечують його комплексну оцінку. Вона містить у собі показники, що характеризують доступність матеріальних благ, ступінь рівності у їх розподілі, купівельну спроможність громадян, їх доходи, гарантований державою мінімальний рівень забезпеченості, тобто беруться до уваги всі економічні ресурси, що має в своєму розпорядженні населення в цілому та його окремі соціально-економічні групи. Інший блок показників включає дані про особисте споживання, i, насамперед, про задоволення основних 
фізіологічних потреб. Він відображає реальні споживчі можливості населення.

Така система показників рівня життя загалом відповідає світовим стандартам. Зважаючи на підсумки Всесвітньої зустрічі на вищому рівні в інтересах соціального розвитку (м. Копенгаген, 1995 р.), у 1997 р. 29-та Статистична Комісія ООН [13] затвердила наступний мінімальний набір соціальних індикаторів, рекомендованих для статистичного спостереження:

а) демографічні показники;

б) макроекономічні показники матеріального добробуту;

в) показники економічної активності населення;

г) показники матеріальної заможності домогосподарств;

д) рівень і структура особистого споживання;

е) житлові умови населення.

При цьому демографічні показники включають чисельність населення, очікувану тривалість життя при народженні, рівень смертності немовлят і материнської смертності, рівень освіти населення, а макроекономічні показники матеріального добробуту об'єднують реальні наявні ресурси, витрати на кінцеве споживання домогосподарств, середньомісячну заробітну плату й інші види доходів.

Склад наведених вище показників і ступінь їх використання можуть змінюватися залежно від того, які аспекти рівня життя населення підлягають аналізу, та від пріоритетності розв’язуваних проблем. Перераховані показники характеризують: людський і трудовий потенціал країни; розмір і джерела формування особистих доходів, а також роль кожного з них; розподіл доходів між окремими групами населення; використання доходів для особистого споживання; обсяги і структуру споживання матеріальних благ і послуг.

Самостійним об'єктом статистичного виміру є бідність як неможливість внаслідок нестачі коштів підтримувати спосіб життя, притаманний конкретному суспільству в конкретний період. Виходячи з нагальної потреби в якнайшвидшому подоланні бідності - однієї з найболючіших проблем суспільства, від якої страждає значна частина населення України (сім’ї з дітьми, діти-сироти, діти, позбавлені батьківського піклування, безробітні, особи з інвалідністю, пенсіонери, бездомні громадяни, безпритульні діти) та яка суттєво обмежує можливості людського розвитку, породжує масштабні соціальні конфлікти, становить загрозу єдності суспільства та національній безпеці України, 26 лютого 2010 р. Президентом України був прийнятий Указ № 274/2010 «Про невідкладні заходи 3 подолання бідності» [14]. Подолання бідності визнано найважливішим пріоритетом у здійсненні реформ в Україні.

Стратегічним напрямом подолання бідності є підвищення зайнятості населення і розвиток ринку праці. Однак бідність не можна подолати лише шляхом підтримки незаможних, потрібні комплексні підходи, орієнтовані як на бідні, так і на відносно забезпечені верстви населення. Необхідною передумовою руху у цьому напрямку є створення працездатному населенню умов для самостійного розв’язання проблем підвищення власного добробуту, що можливо лише в разі 
забезпечення продуктивної зайнятості, збалансування попиту і пропозиції на ринку праці, запобігання безробіттю.

Наступним напрямом подолання бідності є збільшення доходів від трудової діяльності, збільшення рівня заробітної плати як основного джерела доходів населення і забезпечення випереджального зростання номінальної заробітної плати порівняно з ростом споживчих цін, посилення мотивації до продуктивної праці, запровадження погодинної системи оплати праці із застосуванням мінімального розміру погодинної заробітної плати; розвитку соціального партнерства і договірного регулювання трудових відносин у сфері оплати праці, вдосконалення процедури укладання колективних договорів і угод та контролю за їх виконанням.

Дуже важливим елементом у подоланні бідності є розвиток соціального страхування як спосіб захисту особи від втрат доходу і як організаційно-правова форма соціального забезпечення. Соціально-страхова система має бути спрямована на посилення соціального забезпечення конкретних осіб і членів ї сімей від імовірної бідності внаслідок неможливості отримувати дохід у разі втрати роботи або працездатності через хворобу, нещасний випадок, каліцтво, старість чи смерть годувальника.

В. М. Вегера основними пріоритетами соціальної держави в питанні забезпечення достатнього рівня життя називає такі: а) підвищення якості й рівня життя населення; б) чітке розмежування сфер державного і колективно-договірного регулювання оплати праці; в) поступальне зростання мінімального розміру заробітної плати; г) установлення й забезпечення державних гарантій у сфері оплати праці; д) обмеження розмірів утримань із заробітної плати, в тому числі розмірів оподаткування доходів; е) посилення захисту прав працівників на своєчасне й у повному розмірі одержання заробітної плати [15, с. 5-6].

Слушною є думка, що розміри виплат залежать від соціально-економічних можливостей держави, проте повинні забезпечувати конституційне право кожного на достатній життєвий рівень для себе і своєї сім'ї, хоча в зазначеній статті Основного Закону й не закріплюється, що держава його гарантує. Завдання ж держави, яка проголосила себе соціальною, полягає в тому, щоб створити такі умови для людини, аби вона могла своєю працею забезпечити гідну матеріальну базу життєдіяльності для себе і своєї сім'ї. Незважаючи на те, що кожен має піклуватися про власний добробут особисто, держава зобов'язана створювати відповідні умови, щоб людина реально мала змогу забезпечити себе і свою сім'ю. Забезпечення кожного такою можливістю - одне із головних завдань соціальної держави [15, с. 67-68].

3 метою забезпечення конституційного права громадян на достатній життєвий рівень виключно законами встановлюються основні державні соціальні гарантії (мінімальні розміри оплати праці, доходів громадян, пенсійного забезпечення, соціальної допомоги, розміри інших видів соціальних виплат, встановлені законами та іншими нормативно-правовими актами, які забезпечують рівень життя не нижчий від прожиткового мінімуму). Вони є обов’язковими для всіх 
державних органів, органів місцевого самоврядування, підприємств, установ і організацій незалежно від форми власності.

Рівні основних державних соціальних гарантій визначаються на базі державних соціальних стандартів - встановлених законами, іншими нормативно-правовими актами соціальних норм і нормативів або їх комплексу.

Стандарти і нормативи формуються, встановлюються і затверджуються у порядку, визначеному Кабінетом Міністрів України за участю та погодженням з іншими сторонами соціального партнерства. Інший порядок може бути передбачений тільки Конституцією та законами України. Виключно законами України визначаються: мінімальний розмір заробітної плати; мінімальний розмір пенсії за віком; неоподатковуваний мінімум доходів громадян; величина порогу індексації грошових доходів громадян; пільги щодо оплати житлово-комунальних, транспортних послуг і послуг зв’язку та критерії їх надання.

Надання державних соціальних гарантій здійснюється за рахунок бюджетів усіх рівнів, коштів підприємств, установ і організацій та соціальних фондів на засадах адресності та цільового використання. Державні соціальні гарантії та державні соціальні стандарти і нормативи є основою для розрахунку видатків на соціальні цілі та формування на їх основі бюджетів усіх рівнів та соціальних фондів, міжбюджетних відносин, розробки загальнодержавних і місцевих програм економічного і соціального розвитку.

Нормативи фінансування встановлюються під час прийняття Закону України про Державний бюджет України на поточний рік, а також під час формування бюджетів соціальних фондів.

3 метою дотримання державних соціальних гарантій, оцінки ефективності державної соціальної політики, іiї впливу на рівень та якість життя в Україні здійснюється постійний державний моніторинг у сфері застосування та фінансового забезпечення державних соціальних стандартів і нормативів. Основними засобами здійснення такого моніторингу є: щомісячна оцінка вартісної величини основних державних соціальних стандартів; ведення державного статистичного обліку щодо дотримання державних соціальних стандартів і нормативів; поточне коригування вартісних величин державних соціальних нормативів і нормативів витрат (фінансування) залежно від зміни цін та інших умов їх формування. За результатами такого моніторингу здійснюється перегляд розмірів державних соціальних гарантій у порядку, що визначається законами.

Висновки. Поняття «достатній життєвий рівень» чинним законодавством України не визначено, не встановлено також, яким є його співвідношення 3 прожитковим мінімумом. Достатній життєвий рівень не є усталеною величиною, тому що змінюється залежно від соціально-економічних та інших чинників. Завдання держави полягає у створенні належних умов для людини, щоб вона могла своєю працею забезпечити гідну матеріальну базу для себе і своєї сім’і. Притримуємось позиції, що правильніше говорити не про достатній, а про гідний життєвий рівень, адже у першому випадку йдеться про рівень, який фактично відповідає мінімальним потребам людини (тобто мінімальний - той, 
що не є нижчим межі бідності людини), значення ж другого полягає у тому, що це рівень, який виходить із того, що права людини є найвищою соціальною цінністю. Саме гідність дає змогу людині відчувати самоповагу й усвідомлювати власну суспільну цінність. Ця позиція має бути зафіксована й у ст. 48 Конституції України.

\section{Список літератури:}

1. Конституція України від 28.06.1996 р. № 254к/96-ВР. Відомості Верховної Ради України. 1996. № 30. Ст. 141.

2. Про державні соціальні стандарти та державні соціальні гарантії : Закон України від 05.10.2000 р. № 2017-III. Відомості Верховної Ради України. 2000. № 48. Ст. 409.

3. Загальна декларація прав людини ООН від 10.12.1948 р. Документи ООН A/RES/217А : Права людини. Міжнародні договори України, декларації, документи. 2-ге вид. упоряд. Ю. К. Качуренко. Київ : Юрінформ, 1992. С. 18-24.

4. Міжнародний пакт про економічні, соціальні і культурні права ООН від 16.12.1966 р. Вісник Конституиійного Суду Украӥни. 2006. № 4.

5. . Конвенція про права осіб з інвалідністю ООН від 13.12.2006 р. Офічійний вісник України. 2010. № 17. Ст. 799.

6. Про основні цілі та норми соціальної політики : Конв. МОП від 22.06.1962 р., № 117 Конвенції та рекомендації, ухвалені Міжнародною організацією праці : в 2-х т. Т. I (1919-1964). Женева : Міжнар. бюро праці, 1999. С. 688-699.

7. Свропейський кодекс соціального забезпечення від 16.04.1964 p. URL: http://zakon.rada. gov.ua/laws/show/994_329.

8. Хартія Співтовариства про основні соціальні права працівників від 09.12.1989 p. URL: http://zakon.rada.gov.ua/laws/show/994_044.

9. Свропейська соціальна хартія (переглянута) від 03.05.1996 р. Відомості Верховної Ради України. 2007. № 51.

10. Бермічева О. В. Соціальна функція держави в Україні : дис. ... канд. юрид. наук. Харків, 2002. $191 \mathrm{c}$.

11. Мацокін В. В. Право громадян України на достатній життєвий рівень : автореф. дис. ... канд. юрид. наук. Харків, 2008. 20 с.

12. Основи законодавства України про охорону здоров'я : Закон України від 19.11.1992 р. № 2801-XII. Відомості Верховної Ради Украӥни. 1993. № 4. Ст. 19.

13. Феоктистов Д. В. Методология оценки уровня и качества жизни населения. Налоги. Инвестищии. Капитал. 2002. № 3/4. URL: http://nic.pirit.info/200211/021.htm (дата звернення: 22.11.2018).

14. Про невідкладні заходи з подолання бідності : Указ Президента України від 26.02.2010 р. № 274/2010. Офіиійний вісник України. 2010. № 16. Ст. 731.

15. Вегера В. М. Встановлення розміру мінімальної заробітної плати як спосіб державного регулювання оплати праці в Україні. Харків : Право, 2015. 168 с.

\section{References:}

1. Konstitutsiya Ukrayini vid 28.06.1996 r. № 254k/96-VR. (1996). Vidomosti Verkhovnoi Rady Ukrainy, 30, art. 141.

2. Pro derzhavni sotsialni standarti ta derzhavni sotsialni garantiyi: Zakon Ukrayini vid 05.10.2000 r. № 2017-III. (2000). Vidomosti Verkhovnoi Rady Ukrainy, 48, art. 409.

3. Zagalna deklaratsiya prav lyudini OON vid 10.12 .1948 r. (1992). Dokumenti OON A/RES/217A: Prava lyudini. Mizhnarodni dogovori Ukrayini, deklaratsiyi, dokumenti. Yu. K. Kachurenko (Ed.). Kyiv: Yurinform, 18-24 [in Ukrainian].

4. Mizhnarodniy pakt pro ekonomichni, sotsialni i kulturni prava OON vid 16.12.1966 r. (2006). Visnyk Konstytutsiinoho Sudu Ukrainy, 4 [in Ukrainian]. 
5. Konventsiya pro prava osib z invalidnistyu OON vid 13.12.2006 r. (2010). Ofitsijnyj visnyk Ukrainy - Official Gazette of Ukraine, 17, art. 799 [in Ukrainian].

6. Pro osnovni tsili ta normi sotsialnoyi politiki: Konv. MOP vid 22.06.1962 r. № 117 Konventsiyi ta rekomendatsiyi, uhvaleni Mizhnarodnoyu organizatsieyu pratsi: (Vols. 1-2); Vol. 1 (1919-1964). (1999). Zheneva: Mizhnar. byuro pratsi, 688-699 [in Ukrainian].

7. Evropeyskiy kodeks sotsialnogo zabezpechennya vid 16.04.1964 r. URL: http://zakon.rada. gov.ua/laws/show/994_329 [in Ukrainian].

8. Hartiya Spivtovaristva pro osnovni sotsialni prava pratsivnikiv vid 09.12.1989 r. URL: http:// zakon.rada.gov.ua/laws/show/994_044 [in Ukrainian].

9. Evropeyska sotsialna hartiya (pereglyanuta) vid 03.05.1996 r. (2007). Vidomosti Verkhovnoi Rady Ukrainy, 51 [in Ukrainian].

10. Bermicheva, O.V. (2002). Sotsialna funktsiya derzhavi v Ukrayini. Candidate's thesis. Kharkiv [in Ukrainian].

11. Matsokin, V.V. (2008). Pravo gromadyan Ukrayini na dostatniy zhitteviy riven. Extended abstract of candidate's thesis. Kharkiv [in Ukrainian].

12. Osnovi zakonodavstva Ukrayini pro ohoronu zdorov'ya: Zakon Ukrayini vid 19.11.1992 r. № 2801-XII. (1993). Vidomosti Verkhovnoi Rady Ukrainy, 4, art. 19.

13. Feoktistov, D.V. (2002). Metodologiya otsenki urovnya i kachestva zhizni naseleniya. Nalogi. Investitsii. Kapital, 3/4. URL: http://nic.pirit.info/200211/021.htm [in Russian].

14. Pro nevidkladni zahodi z podolannya bidnosti: Ukaz Prezidenta Ukrayini vid 26.02.2010 r. № 274/2010. (2010). Ofitsijnyj visnyk Ukrainy - Official Gazette of Ukraine, 16, art. 731.

15. Vegera, V.M. (2015). Vstanovlennya rozmiru minimalnoyi zarobitnoyi plati yak sposib derzhavnogo regulyuvannya oplati pratsi v Ukrayini. Kharkiv: Pravo [in Ukrainian].

Yaroshenko O. M., Doctor of Law, Professor, Corresponding Member of the National Academy of Legal Sciences of Ukraine, Head of the Department of Labor Law, Yaroslav Mudryi National Law University, Ukraine, Kharkiv.

e-mail : yaroshenkolex@ukr.net ; ORCID 0000-0001-9022-4726

\section{Problems of provision of the citizens' constitutional right to sufficient standard of living}

In accordance with the Constitution of Ukraine of 1996, the state ensures social orientation of the economy (Part 4, Article 13). This, in its turn, is the basis for the implementation of numerous social rights of citizens, in particular to (1) wages, not lower than that established by law (Article 43), (2) social protection (Article 46), and (3) sufficient standard of living for themselves and their families (Article 48). These norms of the Basic Law are implemented by the state social standards and state social guarantees provided for by the current legislation. However, the current national legislation defining the legal framework for the formation and application of the state social standards and norms aimed at implementing the basic social guarantees enshrined in the Constitution and the lawes of Ukraine does not contain a clear and unambiguous answer to the questions of what is a sufficient standard of living, what is the content of the relevant right, and how it is implemented.

The analysis of international documents has shown that to designate actually the same phenomenon different terms are used: "sufficient standard of living"; "decent living standard"; "the standard of living necessary for the maintenance of health and well-being"; "adequate social protection".

It is clear that a sufficient standard of living is not a stated quantity, since it varies depending on socio-economic and other factors. The task of the state is to create the proper conditions for a person so that he/she can by one's own work provide a decent material base for oneself and for the family. The position is advocated that it is more correct to speak not about sufficient but about decent standard of living, since in the first case we talk about a level that actually corresponds to the minimum human needs (that is, equal to or higher than the human poverty line), the importance of the second is that it is the level that goes out from the fact that a person is the highest social value. It is the dignity that allows a person 
to feel self-respect and realize one's own social value. This position should be fixed in Article 48 of the Constitution of Ukraine.

Keywords: social rights; social protection; right to adequate standard of living; state social standards; state social guarantees; cost of living; poverty.

Рекомендоване цитування: Ярошенко О. М. Проблеми забезпечення конституційного права громадян на достатній життєвий рівень. Проблеми законності. 2019. Вип. 145. С. 106-117. doi: https://doi.org/10.21564/2414-990x.145.159672.

Suggested Citation: Yaroshenko, O.M. (2019). Problemy zabezpechennia konstytutsiinoho prava hromadian na dostatnii zhyttievyi riven [Problems of provision of the citizens' constitutional right to sufficient standard of living]. Problemy zakonnosti - Problems of Legality, issue 145, 106-117. doi: https://doi.org/10.21564/2414-990x.145.159672 [in Ukrainian].

Надійшла до редколегії 15.03.2019 р. 